\title{
Surviving Consumerism and Eating Disorders in Margaret Atwood's The Edible Woman
}

\author{
Dr. Prantik Banerjee \\ (Research Supervisor) \\ Associate Professor, Dept. of English \\ Hislop College, Nagpurof Arts \&Social Science, Nagpur
}

\begin{abstract}
The purpose of my paper is to scrutinize closely the concept of social satire, revealing and thereby amending the society's blight in relation to the novel, The Edible Woman by the Canadian author Margaret Atwood.

The novel is unambiguously interested in the complex body truths in the Consumerist Society. In The Edible Woman, Atwood furnish a critique of North American consumer society in the 1960s from a feminist point of view. As a feminist social satire, it takes specific bend at the way society has customised the methods of marginalizing and preventing women from having power, authority and influence. It uses the narrative device of exaggeration to expose some of the negative elements of consumer society, making both funny and bitterly satiric. It provides an early glimpse of the witty characteristic of Atwood's writing style proclaiming a theme that will be a central concern in all her later work-feminism.

The Edible Woman is an exposure of an economically sound woman taking time to be aware of her marginalization as the 'second sex'. Marian, the protagonist, digs deep into the social conditions of the 'archetype' followed by ultimately researching at the 'individuation'. This syndrome by Atwood is categorized as "Rapunzel Syndrome", asserting that in Canada "Rapunzel and the tower are all the same".(Survival: A ThematicGuidetoCanadianLiterature)Marian has to free her from the dragon cage forming her socialized self and live independently without any split between her inner and social self. Yielding to the complications of her society, she struggles to survive in "seemingly sane but actually insane society", which is both predatory and suffocating chauvinist. The novel is a critique of what George Woodcock calls "Emotional Cannibalism". (Woodcock)Her 'struggle' between the societies' executed role and her personal definition of self-- the food becomes a symbolic of that 'struggle' and her 'ultimate revolt'. She shows her vulnerability through her attitude towards food. She ceases to eat, as an objection against capitalism. Towards the end she reconstructs the concept of self through a rehabilitated association with food. These subject matters demonstrate how the body 'caters' to an identity and a woman's corporeal experience directly to her cultural experience. I will argue that how The Edible Woman shows woman's body is always a site of constant struggle between self-control and selfassertion while analyzing the extent to which Atwood's fiction might dismantle culturally-encoded concepts of femininity keeping the problems related to Identity Crisis.
\end{abstract}

Keywords:MargaretAtwood;femininity;gender politics; identity; identity crisis; Anorexia Nervosa;victimization;consumerism; capitalism; suppression

'The Edible Woman is an imaginative transformation of a social problem into comic satire as one young woman rebels against her feminine destiny as the 'edible woman'

- Coral Ann Howells

The Edible Woman by Margaret Atwood is an enduring literary work set in the civil rights era. This novel follows the life of a recent college graduate, Marian MacAlpin, through her career and emotional maturation in a somewhat unnatural, if not threatening world. The queer concept of this world is branded by a spectrum of moral viewpoints of gender politics that manifest themselves and surround Marian. The political and cultural values and practices of a male dominated and sex driven society depicted in the novel are so strong that they seem to devour Marian physically and emotionally. She rebels against this cannibalistic, patriarchal society through a comestible mode and the end, reclaims her identity crisis by restoring her relationship with food.

The novel starts with Marian, the protagonist's first person narrative of her interactions with her defiant roommate, Ainsley, who is intent on becoming a mother, her practical lawyer boyfriend, Peter, and her pregnant and fragile friend, Clara. As the narrative progresses, Marian begins to disassociate herself from her body on 
experiencing the predatory and dangerous nature of the society in which she lives. Marian's victimization leads to her identity crisis, after she accepts Peter's hand in marriage.

When dining with Peter at a restaurant she can see her upside down reflection which reveals that she has moved from a state of certainty to that of uncertainty and her initial solid identity is in a state of flux: she is losing her identity and is controlled by someone else rather than herself. It is Peter who places an order and "chooses her order in the restaurant and this is the moment from which Marian can no longer tolerate food." (Parker) Peter reduces her position to that of a child who needs someone to take decisions for her and is almost a dependent entity: "Peter smiled and chewed, pleasantly conscious of his own superior capacity." (TEW 192) Atwood showed her anxiety and infirmity through her attitude towards food and her lack of appetite which finally leads her to an eating disorder which is similar to Anorexia Nervosa.Peter's domineering ways become evident as the story progresses. Marian develops a relationship with a narcissistic Duncan, an English graduate student, who is shown as Marian's 'alter-ego' and functions as her 'double' throughout the novel. When Marian puts on his grey dressing gown, he comments "you look sort of like me in that". (TEW 181)Duncan is described as "cadaverously thin" with ribs that 'stuck out like those of an emaciated figure in a medieval wood cut' he is also likened to "a starved Buddha burning incense to itself". (TEW 58) His erratic behavior becomes evident when they share an unanticipated, but cherished, kiss at the Laundromat.

When Marian succumbs to Peter's wish to dress up for his party, she experiences her final loss of identity. The overwhelming sense of falseness and destruction at the party has a distressing influence on Marian's mind. She then escapes to find Duncan and hence passes the night with him in a hotel room.

After discovering that more than mere 'prevention' was essential, Marian takes a fundamental step to win back her identity. A very brave move on Marian's part is symbolically showing Peter that she can no longer be controlled. She does this by designing a cake in the image of a male's ideal woman accusing Peter of symbolically devouring her. Hence, a very 'upset' Peter breaks off the engagement. Marian, in a symbolic act of reclaiming her identity, eats the cake voraciously-- and allows Duncan to finish eating the cake along with her. In the end, Marian is able to eat again. She is free to hunger, no longer estranged from her body; Marian is absorbing the power of a woman and her body that she has ignored till now.Atwood, through Marian, lays bare the hypocritical postures of patriarchal society and attempts to "expose and subvert the ideological constructs that have long defined and confined women" (Bouson).This paper maps the story of the Marian, the protagonist, in three stages of the formation of her identity with the course of this eating disorder: Part One shows the background causes with initial identity. Part Two indicates the mind/body split with identity crisis. And Part Three reflects the spontaneous resolution of the problem with reclamation of identity.Through this journey, Marian matures by realizing that she cannot allow herself to be metaphorically and physically consumed.

In the essay, "Reconstructing Margaret Atwood's Protagonists", Patricia Goldblatt states that "Atwood creates situations in which women, burdened by the rules and inequalities of their societies, discover that they must reconstruct braver, self-reliant personae in order to survive." (Goldblatt) Non-eating in The Edible Womanis mainly a symbol of thedenial of the patriarchal model of femininity. Although the protagonist is an educated bright woman who lives on her own, she feels manipulated and unable to take decisions for herself.

The novel deploys the motif of food, metaphorically and physically, through female sexuality, marriage, childbearing. The introspective protagonist, who is rooted in everyday life, experiences a process of development as she apprehends that society has the aptitude to consume her.Margaret Atwood in an interview says:

It's a human activity that has all kinds of symbolic connotations depending on the society and the level of society. In other words, what you eat varies from place to place, how we feel about what we eat varies from place to place, how we feel about what we eat varies from individual as well as from place to place. If you think of food as coming in various categories: sacred food, ceremonial food, everyday food and things that are not to be eaten, forbidden food, dirty food, if you like- for the anorexic ,all food is dirty food. (Lyons)

The study of Marian's initial identity, in the first part of the story is attention-grabbing in both style and context. The first-person narrative seems to be of a regular and present-day atmosphere. Marian's work at Seymour Surveys is more permanent than Ainsley's, but for this reason, it is also more threatening. Marian repetitively morphs her personality to fine-tune Peter's 'temper tantrums'; her world capitulates to a state of irregularity. Peter huffs over his friends 'engagement and marriage referring it as "a national désastre" (TEW 23).Ainsley and Marian's trip to Clara's house for dinner initiates Peter's fear. Clara's house, husband and children offer a comical illustration of chaotic family life. Marian identifies the grotesqueness of Clara's fragile body and way of life as the "normal"-- a normalcy she herself would pursue.

Similarly, Ainsley, who reflects a more radical sentiment of future plans of motherhood, breaks the news that she is "going to have a baby". She posits the "traditional womanhood' concept that "every woman should have at least one baby...It's even more important than sex. It fulfills your deepest femininity" (TEW 41). 
The thought of Ainsley not having a baby in the traditional context, especially without a husband, conveys Marian's initial and conventional moral identity.

Marian tries to equate her normal life with Peter keeping in mind the fact that he is "an ideal choice when you come to think of it. He's attractive and he's bound to be successful, and also he's neat, which is a major point when you're going to be living with someone" (TEW 116). She hence prefers an even number of children and states that she has "never been silly about marriage the way Ainsley is" (TEW 116). However, Marian secretly anticipates her display of normality and conventionalism when she chances upon Duncan, an English graduate student. Duncan's fickleness along with the intimate moment they share shatter Marian's contented and banal lifestyle. In the background causes of the first part of her identity formation Marian is shown to have embarked upon a journey of inner growth. She undertakes an assignment to conduct a survey for a beer advertisement and the world she encounters is represented as agenda-driven and over-sexualized! Marian silently succumbs when she has a chance meeting with a couple who try to propagandize her into the temperance program. A man also tries to mark a sexual pass at her.

Marian encounters a true identity crisis when she is out to drink with Peter, Len and Ainsley. Marian's disassociation from her body begins with Peter's narrating of a gruesome hunting story to Len. Marian realized later that she was crying; "After a while I noticed with mild curiosity that a large drop of something wet has materialized on the table near my hand...I must be crying then!" (TEW 76) On this juncture, she twice breaks away and runs uncontrollably, from her friends and her boyfriend. Peter attempts to scold her by saying, "Ainsley behaved herself properly, why couldn't't you? The trouble with you is ... you're just rejecting your femininity" (TEW 89). Marian later accepts Peter's marriage proposal, challenging her and underlining her crisis of identity. The episode of the 'hunting' and 'sex' creates a vision of male-female relationships in the consumer capitalist society through the novel.

In The Edible Woman, Atwood disassembles the patriarchal concept of femininity and offers a new account of the female body. By re-appropriating the body, Atwood is able to articulate women's anxieties over her oppressive cultural experiences as well as confront that oppression. Her fiction exposes the falsities of mind/body dualisms that alienate woman from her body, and drive her from her somatic self. In so doing, Atwood proposes a transcendence of those falsities and the restricting boundaries they promote. This identity crisis makes a deeper impression in the second part of the novel when she loses her appetite gradually. 'Acceptance' is what her body is crying out for; it refuses to be 'dismissed'. In abstaining from certain foods, Marian faces 'each day with the forlorn hope that her body might change its mind' (TEW 198). Her rejection of food acts as a metaphor for her rejection of the male-dominated society to which she belongs. When Peter proposes, Marian's body starts to refuse food and she is unable to eat. Because she feels like she is being consumed by Peter, she cannot consume food. Not only has she lost her appetite, but also she has lost her sense of self. In order to show how limited are the models offered by society to adult women, Atwood uses food imaginary. The menu, which appears when Marian goes to the restaurant with Peter, represents an illusion of choice. Even though Marian can choose anything from the list of meals, she cannot get anything else. This situation suggests that Marian is trapped by the options presented to her at work and her personal life. For Atwood, the body is a means by which woman can assert her existence, and not a manipulated existence defined for her. In her fiction, Atwood employs a corporeal language of resistance. The female body manifests female powerlessness while simultaneously protesting against it, adapting the eating disorder to this purpose. Atwood's consideration of the female body as a site of power and resistance is one of the most crucial and profound statements of her work.

As Susan Bordo states, these practices of femininity may lead women to "utter demoralization, debilitation and death." (Bordo)As the feminine ideal becomes increasingly confining, she imagine herself disappearing. Sitting in the bath, Marian is suddenly overwhelmed by the fear that she is dissolving, 'coming apart layer by layer like a piece of cardboard in a gutter puddle' (TEW 218). This image is initially introduced by a dream:

I [Marian] had looked down and seen my feet beginning to dissolve, like melting jelly, and had put on a pair of rubber boots just in time only to find that the ends of my fingers were turning transparent. I had started towards the mirror to see what was happening to my face, but at that point I woke up." (TEW 83)

In The Edible Woman, Atwood disassembles the patriarchal concept of femininity and offers a new account of the female body. By re-appropriating the body, Atwood is able to articulate women's anxieties over her oppressive cultural experiences as well as confront that oppression.

But the style which Atwood uses is primarily he manipulation of a shifting narrative point of view and her use of an unbalanced, tripartite structure--reflects a more complex picture of capitalism and female subjectivity in the 1960s.Marian comes to an understanding of the heteronormative and masculine structures that operates in her life through the trope of food. She asks Ainsley of her normality and she ambiguously replies back, "Normal isn't the same as average...nobody is normal." (TEW 239). Marian's identity crisis reaches an acute stage with Peter's proposal to her to get ready for the party he is hosting. She does not even identify herself rather stating, 
"three reflections of [herself] at the same time...watching the way in which different bright silver parts of her body suddenly bloated or diminished."

Marian, in the third and final part of the story sets out to reclaim her identity. She is no longer governing her body so she slips out from the party to make love with Duncan in a shady hotel room. Following the night's affair, Marian comprehends that she must regain her identity by baking the 'woman-shaped -cake' that she bakes for Peter, who he wanted her to be and whom he wanted to consume.

Marian desires a classical, clean and proper body. She contemplated the cake "its doll-like face and vacant except for the small silver glitter of intelligence in each green eye" Marian turned pensive after anticipating the whole fact... "All that work gone into the lady and now what would happen to her?" (TEW 298). Marian lastly implores Peter with the accusation, "You have been trying to destroy me, haven't you...You've been trying to assimilate me. But, I've made you a substitute, something you'll like much better" (TEW 299). The "cake lady" she offers to her fiancé at the end is "a substitute" (TEW 278) for herself, as a sacrifice which can undergo the fate she therefore escapes - of being "morselized". The ultimate cannibalistic intake of the cake sketches out the re-consumption of herself with the retrieval of her own person. She goes on making a decision of who can consume the substitute she created-- thus demonstrating her acceptance over Duncan as the 'new man' by offering him the cake.It describes how the desire returns and at the same time Marian comes back to herself. The 'edible woman' can eat again!

Overall, The Edible Woman by Margaret Atwood scrutinizes Marian's survivalwithsuppressionamidst identity crisis by representation of food. The distinction between edible and non-edible, in relation to consumerism gets analyzed, in this novel, through Marian's predicament in a male-dominated and cannibalistic society. Marian's ability to reclaim her identity by devouring her "woman made out of cake" ravenously (TEW 301 ), helps her womanly strength to get freed from the conformist path of marriage and victimization to Peter. Her incapability to consume food shows her refusal to submit to the traditional culture of female consumerism, allowing her the lack of restrictions. Finally, Marian's protest over the gender politics challenges her to survive by creating a substitute for the consumption of women in society. The novel reflects the constant theme of lack of distinct identity. In this case the character demonstrates the large quantities of strength necessary to protect her own individuality, which was slowly degenerating all because of the communities in which she lived.

Margaret Atwood employs an eating disorder in her novel The Edible Woman as a metaphor of revolt and protest. Marian McAlpin interprets the world in terms of food and negotiates her way using it. Her initial lack of appetite finally leads to Anorexia Nervosa, which is her body's response to the society's attempt of imposing its rules on her. The novel is a critique of capitalism and the consumptive nature of its reality and society. Food is both a product and ingredient of this system. In capitalist society, 'eating' means gaining power to those who are consumers of this culture and the victims of it. As a part of the capitalist society, Marian is also pre-occupied with consumerism at the beginning of the novel. According to Mervyn Nicholson, Anorexia Nervosa does not mean lack of appetite at all, but it means "lack of desire" (Hobgood). This statement allows considering Marian's eating disorder as a resistance to consumerism and her rejection of capitalism which is based on desiring things.

\section{WORKS CITED}

Primary source:

Atwood, Margaret

TheEdibleWoman; London: Virago Press; 1998

Secondary sources:

\section{WORKS CITED}

[1] Atwood, Margaret 1972. Survival: The Thematic Guide to Canadian Literature MacMillanWelton, Donn (ed.)

[2] Bordo, Susan. 2003. Unbearable Weight: Feminism, Western Culture and the Body. London: University of California Press, Ltd.

[3] Lyons, Brooke. , 1992. Using other people's Dreadful Childhoods. In

[4] Ingersoll, EG (ed) Margaret Atwood. Conversation, London: Virago, 221-33

[5] Gold blatt, Patricia F. 'Reconstructing Margaret Atwood's Protagonists' "World Literature Today", Volume: 73.Issue: 2

[6] Parker, Emma "You are what you eat: the politics of eating in the novels of

[7] Margaret Atwood" in Twentieth Century Literature, Vol.41

[8] Hobgood, Jennifer. "Anti-edibles and schizophrenia in Margaret Atwood's The Edible Woman" in Style, Vol.36.1, Northern Illinois University 
[9] Cooke,Nathaile: 'Food and the Edible Woman'

[10] J. Brooks Bouson, "The Anxiety of Being Influenced: Reading and Responding

[11] to Character In Margaret Atwood's The Edible Women”, Style 24. 2 (Summer, 1990):

[12] p. 230.

[13] Parker, Emma; "You are What You Eat'ThePolitics of eating in the novels of Margaret Atwood", Twentieth Century Literature; 1996

[14] Woodcock, George; The Literary Half-Yearly,13,No.2,(July 1972) 237 English 